\title{
Correction to: Effects of a multi-level intervention on the pattern of physical activity among in-school adolescents in Oyo state Nigeria: a cluster randomised trial
}

Mojisola Morenike Oluwasanu* and Oladimeji Oladepo

\section{Correction}

After publication of the article [1], it has been brought to our attention that there is an error in figure 1. The number of excluded secondary schools should read " 50 " and not "72". The rest of the data in the figure is accurate.

Received: 27 October 2017 Accepted: 30 October 2017

Published online: 06 November 2017

\section{Reference}

1. Oluwasanu M, Oladepo O. Effects of a multi-level intervention on the pattern of physical activity among in-school adolescents in Oyo state Nigeria: a cluster randomised trial. BMC Public Health. 2017;17(1):833. https://doi.org/10.1186/s12889-017-4781-y.

* Correspondence: ope3m@yahoo.com

The online version of the original article can be found under doi:10.1186/ s12889-017-4885-4

African Regional Health Education Centre, Department of Health Promotion and Education, Faculty of Public Health, College of Medicine, University of Ibadan, Ibadan, Nigeria 